\title{
Pre-Mining Pattern of Soils on Nauru, Central Pacific ${ }^{1}$
}

\author{
R. Fobn Morrison ${ }^{2}$ and Harley I. Manner ${ }^{3}$
}

\begin{abstract}
The environment of Nauru, a raised atoll located in the central Pacific Ocean $\left(0^{\circ} 32^{\prime} \mathrm{S}, 166^{\circ} 56^{\prime} \mathrm{W}\right)$, was devastated by mining of phosphate "rock" during the twentieth century. Some 100 million tonnes of phosphate material has been removed, leaving more than $80 \%$ of the island as a dolomite pinnacle-dominated karrenfeld. Based on fieldwork examining sites unmined at that time, laboratory studies on undisturbed profiles, aerial photographs, and old mining maps, a picture of what the soil pattern on Nauru was before mining has been developed. Four major soil associations were identified: the coastal fringe carbonate-dominated soils set on a recent fringing reef; deep and relatively deep phosphate-dominated soils free of substantial influence from the underlying dolomite pinnacles occurring on the NE, NW, SE, and SW sectors of the uplifted section of the island (known locally as "Topside"); a complex set of soils found on Topside and on the scarp where the pinnacle influence is important but containing some deep soils where phosphate material accumulated between the pinnacles; and a complex set of soils in low-lying areas around the old lagoon at Buada. Distribution of soils is discussed and physical, chemical, and mineralogical properties of the soils are presented. Soils were basically AC profiles, with coarse textures, free drainage, and limited moisture-retention capacities. Organic matter accumulated to various depths from about 5 to $50 \mathrm{~cm}$. Soil $\mathrm{pH}$ was generally above 6, cation exchange capacities were closely aligned to organic matter contents, but trace element deficiencies would have been common. Cadmium concentrations were relatively high in Nauru soils. The soils are likely to have been of limited fertility, with moisture being a major limitation in many years. Classification of the soils indicated a dominance of Ustropepts and Ustolls, with smaller areas of Ustipsamments and Ustorthents, and very small areas of soils showing aquic features. The postmining situation is also discussed; only very limited areas of three of the original soil associations remain (the relatively deep profiles free of pinnacle influence have completely disappeared). Limitations to rehabilitation are also briefly reviewed.
\end{abstract}

The environment of Nauru was devastated by mining of phosphate "rock" during the twentieth century. Nauru is a raised atoll

\footnotetext{
${ }^{1}$ Manuscript accepted 7 October 2004.

${ }^{2}$ School of Earth and Environmental Sciences, University of Wollongong, NSW 2522, Australia (e-mail: john_morrison@uow.edu.au).

${ }^{3}$ College of Arts and Sciences, University of Guam, Mangilao, Guam 96923 (e-mail: hmanner@uog9.uog .edu).
}

Pacific Science (2005), vol. 59, no. 4:523-540

(C) 2005 by University of Hawai'i Press

All rights reserved located in the central Pacific Ocean $\left(0^{\circ} 32^{\prime} \mathrm{S}\right.$, $166^{\circ} 56^{\prime} \mathrm{W}$ ), with an area of $22.6 \mathrm{~km}^{2}$ and a highest point approximately $70 \mathrm{~m}$ above mean sea level. The limestone was covered with a substantial deposit of phosphatic material, the origin of which has not yet been fully explained. The soils of Nauru are being rapidly removed by phosphate mining operations, with about 100 million tonnes being extracted by surface mining during the last 100 years (D. Scott, General Manager, Nauru Phosphate Corporation, pers. comm., 1998), such that $80 \%$ of the island has been directly impacted by mining. During this mining it has been estimated that the elevation of the island has, on average, decreased by about 6 
m. A stockpile of topsoil is being accumulated that may be used in postmining rehabilitation. Apart from chemical analyses carried out as part of the evaluation of the phosphate deposits, and a brief unpublished report by Phillips and Haantjens (1954), little information on the soils is available.

In 1980, the University of the South Pacific was asked by the Government of Nauru to examine the ecology of Nauru to determine the impact of mining, including changes in vegetation and soils. Patterns of natural regeneration postmining were also to be investigated. The objectives with regard to the soils were as follows: (1) to survey unmined areas to gather information on the soils before mining; (2) to assess the extent and rate of soil regeneration after mining; and (3) to review information on special issues such as the concentrations of $\mathrm{Cd}$ in the soils.

This work was carried out over the following $10 \mathrm{yr}$ and several publications have resulted (e.g., Manner et al. 1984, 1985, Manner and Morrison 1991, Thaman 1992, Thaman et al. 1994). In this paper, information collected on the soils that gives clues to the pre-mining soil pattern is presented. Some comments on the postmining "soil" pattern are also included. This information is extremely important for overall evaluation of the impacts of mining and also to provide a baseline for studies on the long-term evolution of the environment on Nauru.

\section{General Environmental Features of Nauru}

Nauru consists of a raised karstified coral platform at $40-60 \mathrm{~m}$ elevation that was mostly covered by phosphatic material before mining, with a surrounding Holocene fringing coral platform $(<5 \mathrm{~m}$ elevation) varying in width from 100 to $350 \mathrm{~m}$. A number of depressions occur in the upper platform (known locally as "Topside"), with one major depression in the southwest area (the Buada Lagoon) where the elevation falls to close to sea level (Figure 1). The island is surrounded by a living reef with the reef crest lying between 100 and $300 \mathrm{~m}$ offshore. Most of the reef is exposed at low tide. From the crest, the reef drops off rapidly ( $34^{\circ}$ slope) seaward to the ocean floor at a depth of about 4,300 m (Hill and Jacobson 1989).

Nauru lies in the central Pacific Ocean and has a typical oceanic climate with high humidity and relatively constant temperatures around $28-30{ }^{\circ} \mathrm{C}$. As will be discussed later in this article, rainfall is quite variable, averaging about $2,000 \mathrm{~mm}$ per annum. The population of about 10,000 lives mainly along the coastal fringe, with a small settlement around Buada Lagoon. There is very limited agricultural production, with some local gardens producing coconuts, papaya, and vegetables with pigs and chickens for local consumption. Limited fishing activity provides additional protein, but the vast bulk of foodstuffs is imported. Groundwater resources are available and utilized but have to be supplemented with imported water during dry years.

\section{Mining Activity}

The mineable depths of the phosphate deposit (to the base of the pinnacles) varied up to a maximum of $24 \mathrm{~m}$. Initially mining was mainly by hand, but the use of mechanical equipment became important after World War I. Since the 1970s, the mining has involved removal of vegetation, scraping and stockpiling of topsoil (for future remediation), leaving a relatively level surface, followed by excavation of the phosphate material from on top and between the pinnacles using mechanical 0.48 - to $0.76-\mathrm{m}^{3}$ power "grab buckets" (Ruston Bucyrus). The mined material has been stockpiled, sorted, transported to storage near the coast, and then loaded onto ships using sophisticated cantilevers because the island has no harbor suitable for large vessels. No attempt has been made to remediate areas after mining and they remain a karrenfeld (weathered karst limestone showing small weathering features) of pinnacles (some several meters high), with small residual quantities of phosphate materials in the crevices. The landscape is difficult to traverse and no utilization of the area is made apart from small areas flattened for a sports field, landfill, and temporary housing. 


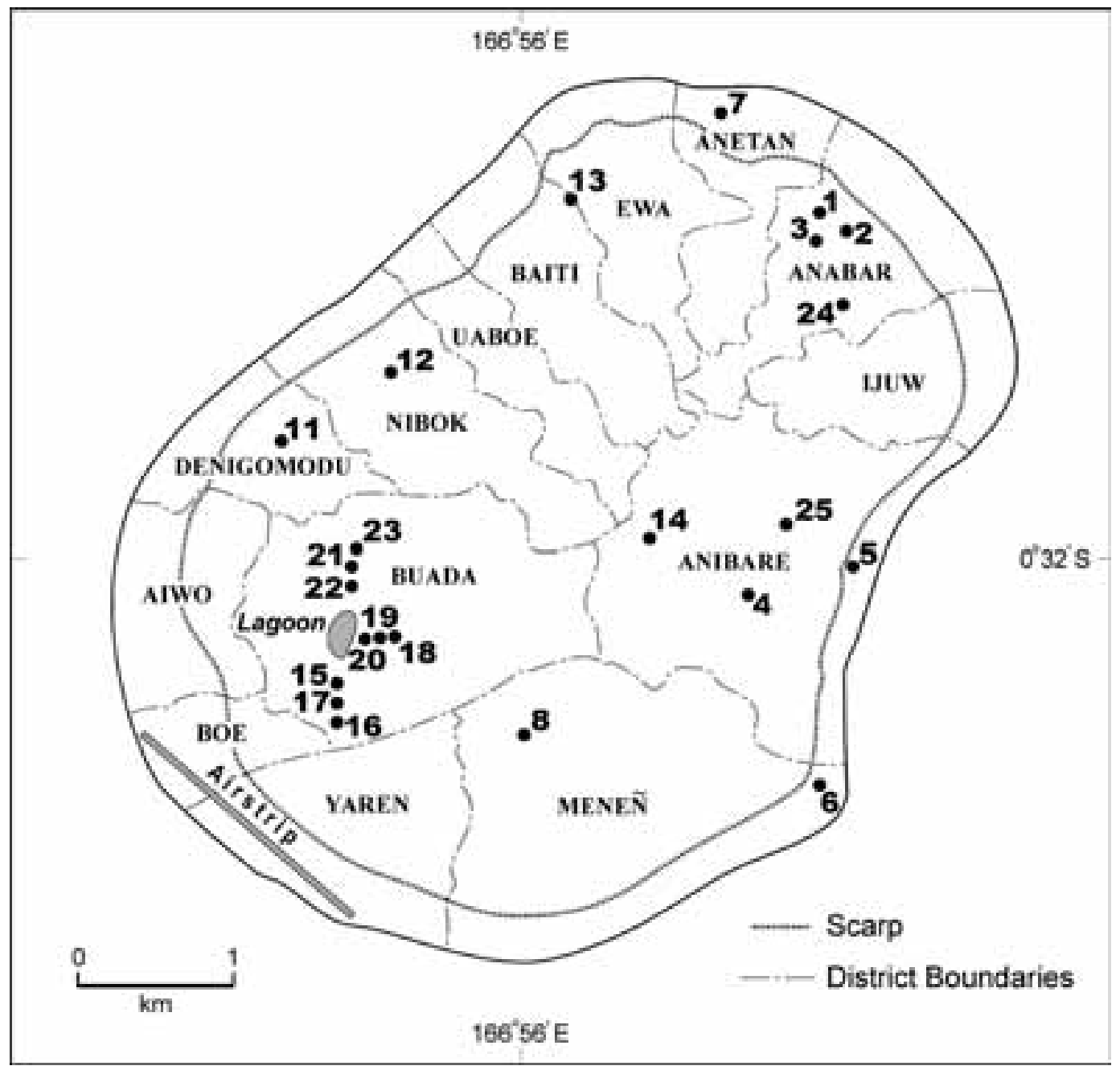

Figure 1. Map of Nauru with district names and sampling sites shown. Numbered sampling sites are described in Table 1.

MATERIALS AND METHODS

\section{Field Studies}

After a reconnaissance survey of the whole island, areas where mining had not occurred were identified. On the north and east of the island, substantial undisturbed areas (in 1980-1984) were identified, but it was difficult to find undisturbed sites in the southwestern section. Discussions were held with local elderly residents who had been involved in the mining to gather information on the nature of the soils in the mined-out areas before this study. Within each area identified, a preliminary auger survey was made to determine the extent of soil variability and the general soil pattern and to identify important soils. Pits were dug in each of the important soils at each area, the profiles described, and samples of soils and parent materials collected 
for laboratory examination. Over 20 pedons were described from Topside, and a few representative pedons from the coastal bottomlands were also examined, giving very good coverage of all the undisturbed areas when fieldwork was completed. The sites of the pedons described are listed in Table 1 and shown in Figure 1. Full descriptions are available in Morrison (1987). Utilizing all the available information, a soil map indicating the likely distribution of soils before mining was prepared.

Assessment of aerial photographs plus topographic and mining maps made available by the Nauru Phosphate Corporation produced at various times during the twentieth century was of value in preparing an overall map of the likely pre-mining island surface and the soil distribution pattern.

\section{Laboratory Studies}

Mineralogical studies were made on whole soil samples $(<200$ mesh, air dry powder $)$ using X-ray diffraction (Morrison 1991). Chemical parameters were measured using the methods of Blakemore et al. (1981) with the following exceptions. Organic carbon was determined by the Walkley-Black procedure with silver sulphate added to the sulphuric acid to remove the interference from chloride ion (Lee et al. 1982). Phosphorus extractable in sodium bicarbonate $(0.5 \mathrm{~mol} /$ liter) after shaking for $0.5 \mathrm{hr}$ (Olsen procedure) at a soil solution ratio of $1: 10$ was determined as described by Barrow and Shaw (1977). Total phosphorus was determined by digesting soil samples in a mixture of nitric and hydrochloric acids, and analyzing the resulting solutions for phosphorus colorimetrically (Murphy and Riley 1962). Calcium carbonate was determined by measuring the carbon dioxide evolved on treatment with dilute hydrochloric acid.

Water retention against $1,500 \mathrm{kPa}$ suction was determined on air-dried samples using a Paton pressure plate apparatus as described by Gangaiya et al. (1982). Water retention against $30 \mathrm{kPa}$ pressure (field capacity) was measured by saturating samples for $24 \mathrm{hr}$, allowing them to drain for $48 \mathrm{hr}$, and measur- ing the retained water by oven drying at $105{ }^{\circ} \mathrm{C}$. Particle size analyses were carried out on field moist samples after destruction of organic matter using hydrogen peroxide. After washing and sieving through a $63-\mu \mathrm{m}$ sieve material retained was sorted into different sand fractions by sieving and weighed. The material passing the $63-\mu \mathrm{m}$ sieve was dispersed in sodium hexametaphosphate/sodium carbonate $(\mathrm{pH} 8)$, and the sedimentation measurements were carried out using a hydrometer.

\section{RESULTS AND DISCUSSION}

\section{Factors of Soil Formation on Nauru}

climate. Located on the equator and having very low elevation, Nauru has a typical oceanic climate with high humidity (usually $>75 \%)$ and relatively constant temperatures (maximum range $23-35^{\circ} \mathrm{C}$ but monthly average $27-29^{\circ} \mathrm{C}$ ). The size of the island prevents any substantial orographic effects on rainfall. The rainfall pattern is extremely variable, with the wettest year being 1930 with 4,590 $\mathrm{mm}$, and the driest 1950 with $280 \mathrm{~mm}$, with a mean (1916-1986) of $1,994 \mathrm{~mm} / \mathrm{yr}$ (Commission of Inquiry 1988). Figure 2 gives an indication of the variation in rainfall over the latter part of the twentieth century. Analysis of monthly rainfall data (not reported here) shows that there is generally a wetter season from November to April and a drier season from May to October. There has been a sixor sevenfold variation in annual rainfall (577$3,991 \mathrm{~mm}$ ), and Nauru experienced well above average rainfall in the El Niño years (1977, 1982, 1987, 1992). In the dry years, the rainfall occurred in different parts of the year (e.g., October-December in 1984, JanuaryJune in 1988). Given the isolation of the island, such variations in rainfall are probably the usual condition.

Analysis of $70 \mathrm{yr}$ of rainfall data from 1916 to 1993 (several years lost due to World War II) showed that "average" annual rainfall only occurred in about $1 \mathrm{yr}$ in five, and belowaverage rainfall occurred in about $55 \%$ of years. Calculations of potential evapotranspiration gave average figures of $120-160 \mathrm{~mm}$ 
TABLE 1

Locations and Grouping of Soils Examined on Nauru

\begin{tabular}{|c|c|c|}
\hline Pedon No. & Location & Soil Group/Taxonomy \\
\hline 1 & Anabar District; $0^{\circ} 30^{\prime} 34^{\prime \prime} \mathrm{S}, 166^{\circ} 56^{\prime} 50^{\prime \prime} \mathrm{E}$ & Deep Topside soil/Typic Haplustoll \\
\hline 2 & $\begin{array}{l}\text { Anabar District; } 100 \mathrm{~m} \mathrm{SE} \text { of site } 1 ; 0^{\circ} 30^{\prime} 35^{\prime \prime} \mathrm{S} \text {, } \\
166^{\circ} 56^{\prime} 52^{\prime \prime} \mathrm{E}\end{array}$ & Deep Topside soil/Typic Ustropept \\
\hline 3 & Anabar District; $0^{\circ} 30^{\prime} 36^{\prime \prime} \mathrm{S}, 166^{\circ} 56^{\prime} 51^{\prime \prime} \mathrm{E}$ & $\begin{array}{l}\text { Moderately deep Topside soil/Typic } \\
\text { Ustropept }\end{array}$ \\
\hline 4 & $\begin{array}{l}\text { Anibare District; } 1,350 \mathrm{~m} \text { E of Topside workshop; } \\
0^{\circ} 32^{\prime} 04^{\prime \prime} \mathrm{S}, 166^{\circ} 56^{\prime} 35^{\prime \prime} \mathrm{E}\end{array}$ & Shallow Topside soil/Lithic Ustorthent \\
\hline 5 & $\begin{array}{l}\text { Anibare District; about } 30 \mathrm{~m} \mathrm{~W} \text { of main road; } \\
0^{\circ} 31^{\prime} 51^{\prime \prime} \mathrm{S}, 166^{\circ} 57^{\prime} 05^{\prime \prime} \mathrm{E}\end{array}$ & Shallow recent soil/Typic Troporthent \\
\hline 6 & $\begin{array}{l}\text { Meneñ District; about } 30 \mathrm{~m} \mathrm{E} \text { of main road; } \\
0^{\circ} 32^{\prime} 30^{\prime \prime} \mathrm{S}, 166^{\circ} 56^{\prime} 51^{\prime \prime} \mathrm{E}\end{array}$ & Shallow recent soil/Lithic Ustipsamment \\
\hline 7 & Anetan District; $0^{\circ} 30^{\prime} 15^{\prime \prime} \mathrm{S}, 166^{\circ} 56^{\prime} 23^{\prime \prime} \mathrm{E}$ & Shallow recent soil/Lithic Troporthent \\
\hline 8 & Meneñ District; $0^{\circ} 32^{\prime} 17^{\prime \prime} \mathrm{S}, 166^{\circ} 56^{\prime} 07^{\prime \prime} \mathrm{E}$ & $\begin{array}{l}\text { Moderately deep Topside soil/Typic } \\
\text { Haplustoll }\end{array}$ \\
\hline 11 & $\begin{array}{l}\text { Denigomodu District; } 30 \mathrm{~m} \mathrm{E} \text { of running track; } \\
0^{\circ} 31^{\prime} 21^{\prime \prime} \mathrm{S}, 166^{\circ} 55^{\prime} 05^{\prime \prime} \mathrm{E}\end{array}$ & Shallow Topside soil/Lithic Ustropept \\
\hline 12 & $\begin{array}{l}\text { Nibok District; } 20 \mathrm{~m} \mathrm{~W} \text { of running track; } \\
0^{\circ} 31^{\prime} 11^{\prime \prime} \mathrm{S}, 166^{\circ} 55^{\prime} 30^{\prime \prime} \mathrm{E}\end{array}$ & $\begin{array}{l}\text { Moderately deep Topside soil/Typic } \\
\text { Ustropept }\end{array}$ \\
\hline 13 & $\begin{array}{l}\text { Baiti-Ewa District boundary; } 0^{\circ} 30^{\prime} 33^{\prime \prime} \mathrm{S} \text {, } \\
166^{\circ} 56^{\prime} 03^{\prime \prime} \mathrm{E}\end{array}$ & $\begin{array}{l}\text { Moderately deep Topside soil/Typic } \\
\text { Ustropept }\end{array}$ \\
\hline 14 & Anibare District; $0^{\circ} 31^{\prime} 42^{\prime \prime} \mathrm{S}, 166^{\circ} 56^{\prime} 17^{\prime \prime} \mathrm{E}$ & $\begin{array}{l}\text { Moderately deep Topside soil/Typic } \\
\text { Ustropept }\end{array}$ \\
\hline 15 & $\begin{array}{l}\text { Buada District; approx. } 250 \mathrm{~m} \text { SSW of lagoon; } \\
0^{\circ} 32^{\prime} 17^{\prime \prime} \mathrm{S}, 166^{\circ} 55^{\prime} 16^{\prime \prime} \mathrm{E}\end{array}$ & $\begin{array}{l}\text { Moderately deep Topside soil/Typic } \\
\text { Ustropept }\end{array}$ \\
\hline 16 & $\begin{array}{l}\text { Buada District; approx. } 400 \mathrm{~m} \mathrm{SSW} \text { of lagoon; } \\
0^{\circ} 32^{\prime} 24^{\prime \prime} \mathrm{S}, 166^{\circ} 55^{\prime} 16^{\prime \prime} \mathrm{E}\end{array}$ & $\begin{array}{l}\text { Moderately deep Topside soil/Typic } \\
\text { Ustropept }\end{array}$ \\
\hline 17 & $\begin{array}{l}\text { Buada District; approx. } 300 \mathrm{~m} \mathrm{SSW} \text { of lagoon; } \\
0^{\circ} 32^{\prime} 21^{\prime \prime} \mathrm{S}, 166^{\circ} 55^{\prime} 16^{\prime \prime} \mathrm{E}\end{array}$ & $\begin{array}{l}\text { Moderately deep Topside soil/Typic } \\
\text { Ustropept }\end{array}$ \\
\hline 18 & $\begin{array}{l}\text { Buada District; top of ridge on E side of lagoon; } \\
0^{\circ} 32^{\prime} 07^{\prime \prime} \mathrm{S}, 166^{\circ} 55^{\prime} 32^{\prime \prime} \mathrm{E}\end{array}$ & $\begin{array}{l}\text { Moderately deep Topside soil/Typic } \\
\text { Ustropept }\end{array}$ \\
\hline 19 & $\begin{array}{l}\text { Buada District; midslope on E side of lagoon; } \\
0^{\circ} 32^{\prime} 07^{\prime \prime} \mathrm{S}, 166^{\circ} 55^{\prime} 28^{\prime \prime} \mathrm{E}\end{array}$ & Shallow Topside soil/Lithic Haplustoll \\
\hline 20 & $\begin{array}{l}\text { Buada District; } 50 \mathrm{~m} \mathrm{E} \text { of eastern lagoon shore; } \\
0^{\circ} 32^{\prime} 07^{\prime \prime} \mathrm{S}, 166^{\circ} 55^{\prime} 25^{\prime \prime} \mathrm{E}\end{array}$ & $\begin{array}{l}\text { Moderately deep Topside soil/Typic } \\
\text { Haplustoll }\end{array}$ \\
\hline 21 & $\begin{array}{l}\text { Buada District; approx. } 300 \mathrm{~m} \mathrm{~N} \text { of lagoon; } \\
0^{\circ} 31^{\prime} 57^{\prime \prime} \mathrm{S}, 166^{\circ} 55^{\prime} 18^{\prime \prime} \mathrm{E}\end{array}$ & $\begin{array}{l}\text { Moderately deep Topside soil/Typic } \\
\text { Haplustoll }\end{array}$ \\
\hline 22 & $\begin{array}{l}\text { Buada District; approx. } 250 \mathrm{~m} \mathrm{~N} \text { of lagoon; } \\
0^{\circ} 31^{\prime} 45^{\prime \prime} \mathrm{S}, 166^{\circ} 55^{\prime} 18^{\prime \prime} \mathrm{E}\end{array}$ & $\begin{array}{l}\text { Moderately deep Topside soil/Typic } \\
\text { Haplustoll }\end{array}$ \\
\hline 23 & $\begin{array}{l}\text { Buada District; } 400 \mathrm{~m} \mathrm{~N} \text { of lagoon; } 0^{\circ} 31^{\prime} 43^{\prime \prime} \mathrm{S} \text {, } \\
166^{\circ} 55^{\prime} 19^{\prime \prime} \mathrm{E}\end{array}$ & $\begin{array}{l}\text { Moderately deep Topside soil/Typic } \\
\text { Haplustoll }\end{array}$ \\
\hline 24 & Anabar District; $0^{\circ} 30^{\prime} 56^{\prime \prime} \mathrm{S}, 166^{\circ} 56^{\prime} 52^{\prime \prime} \mathrm{E}$ & Deep Topside soil/Typic Ustropept \\
\hline 25 & Anibare District; $0^{\circ} 31^{\prime} 39^{\prime \prime} \mathrm{S}, 166^{\circ} 56^{\prime} 48^{\prime \prime} \mathrm{E}$ & $\begin{array}{l}\text { Moderately deep Topside soil/Typic } \\
\text { Ustropept }\end{array}$ \\
\hline
\end{tabular}

per month. In an average year, this indicates a moisture surplus, but given the large variations in annual rainfall and rainfall distribution such estimates have little significance. The calculations do show that moisture deficit in soils occurred for several months in at least 3-4 yr out of ten.

Winds are generally from the northeast, east, or southeast and provide a welcome cooling influence. Usual wind speeds are $5-10$ knots $(9-18 \mathrm{~km} / \mathrm{hr})$, but winds up to $30-35$ knots $(55-65 \mathrm{~km} / \mathrm{hr})$ occur on rare occasions. Nauru is out of the current Pacific cyclone belts.

From a pedological perspective, the climate of Nauru probably has been warm 


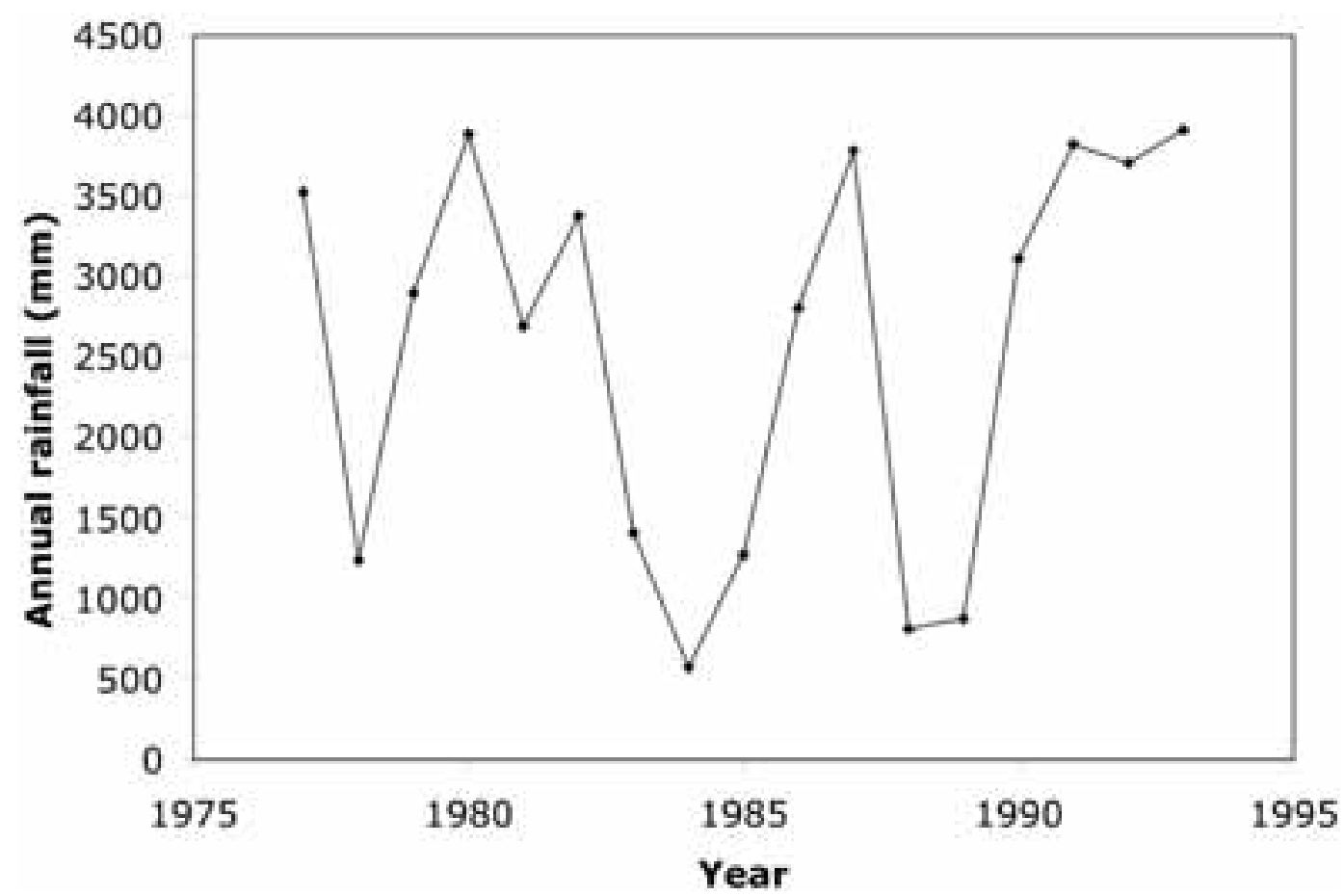

Figure 2. Annual rainfall on Nauru, 1977-1993 (G. Smith, Nauru Phosphate Corporation, pers. comm.).

and humid for long periods, but the rainfall has varied depending on global forces. For example, it is probable that drier climates occurred in the glacial periods, and this has been postulated as being one factor in the genesis of the phosphate rock (Hutchinson 1950). This is discussed further later in this article.

PARENT MATERIAL. Three different parent materials have been identified for the soils of Nauru: phosphate material, usually unconsolidated but rocky in a few places; dolomitic limestone derived from the pinnacles covering the basement of Topside; and reef limestone on the coastal fringe. The hardness and relative resistance of the pinnacles indicates that the dolomitic limestone from that source is a minor contributor to the soil parent material.

The phosphate material has been shown to be very pure apatite (Roe and Burnett 1985, Morrison 1987, Commission of Inquiry 1988), with a $\mathrm{P}$ content averaging about $15 \%$ but ranging from 6 to $18 \%$. The $\mathrm{F}$ concen- tration (1.7-3.0\% [Roe and Burnett 1985]) is generally slightly below that required for pure fluoroapatite, with some hydroxy and carbonate groups incorporated into the apatite. Ca concentrations are around $37 \%$, with $\mathrm{Mg}$ varying from 0.5 to $8 \%$.

Materials forming the pinnacles have been shown to be dominated by dolomite (no other mineral could be identified by X-ray diffraction [Morrison and Bonato, unpubl. data]), with most samples showing a $\mathrm{Ca}: \mathrm{Mg}$ mole ratio very close to $1: 1$ and little variation found within a pinnacle. Typical samples have $\mathrm{Ca} 21.8 \%, \mathrm{Mg} 12.8 \%$, and carbonate $54.0 \%$. Pinnacle materials were also found to contain substantial concentrations of $\mathrm{Cd}$ (1,680-3,940 mg/kg [R.J.M., unpubl. data]).

Samples collected from the sea-level fringing reef have been shown to be mostly reef limestone containing small quantities of dolomite and phosphate, with aragonite and calcite both present (Morrison 1987, Jacobson and Hill 1988). 
The parent materials of Nauruan soils are either resistant to weathering (apatite) or weather relatively easily (limestone by dissolution) without producing new minerals.

RELIEF. The landform on Nauru is made up essentially of three sections: relatively flat coastal fringe, steep scarp, and rolling terrain on Topside. The relatively flat coastal fringe runs into a steep scarp leading up to Topside. Slopes in excess of $30^{\circ}$ have been found, with western slopes often steeper than eastern slopes. There are also some steep slopes around the Buada Lagoon, especially on land rising up to the main upper surface of Topside east of the lagoon. Topside is now a fractured karrenfeld (Barrett 1988) of rugged pinnacles left behind after mining, but field observations in 1980 and study of earlier photographs shows that before mining it was mainly undulating terrain with a number of depressions. The highest points were generally around the edges of Topside, leading to speculation that Nauru may have existed at one time as an atoll. This is confirmed by comments in Power (1904) and a map in Hutchinson (1950). Isolated pinnacles or small groups of pinnacles occur at several spots on Topside above the phosphate.

Another aspect of relief not immediately obvious is the influence of the pinnacles. In some areas these come to the soil surface (even above in places), but in others one had to dig down $2-5 \mathrm{~m}$ to contact pinnacles. This obviously has a major influence on soil properties (e.g., unevenly distributed impervious layers close to the soil surface limit rooting and soil drainage).

HYDROLOGY. Nauru has very limited surface water. Basically there is only the Buada Lagoon and the small brackish lagoons in the north (Anabar and Anetan) and southeast (Meneñ) of the island that sit on the saltwater base within the carbonaceous substratum of the island. There are no surface streams or creeks to create gullies or other landscape changes. Most of the island surface is very porous, consisting of carbonate reef material and unconsolidated phosphatic material. Infiltration rates are high, and moisture retention in soils and other near-surface materials is low. organisms. The original vegetation of Nauru was discussed in some detail by Manner et al. (1984, 1985), Thaman (1992), and Thaman et al. (1994). In summary, the vegetation was similar to that of other upraised limestone islands in Micronesia. This vegetation can be classified into four major types: (1) plateau limestone forest; (2) escarpment or pinnacle forest; (3) wetland and mangrove vegetation; and (4) coastal/strand vegetation.

Data from a few small relict stands studied in 1980-1981 indicated that the forest of the upraised central plateau was fairly open and dominated by Calophyllum inophyllum (tomano), a low branching tree that reaches about $16 \mathrm{~m}$ in height. Other components of the forest were Guettarda speciosa, Premna serratifolia, Terminalia catappa, and Psidium guajava (introduced species). Understory species included Scaevola taccada, Morinda citrifolia, Lantana camara (introduced species), Polypodium scolopendria, and Nephrolepis biserrata. In places, Nauruans planted cultivars of Pandanus tectorius, mainly for its edible fruit.

On the escarpment and large emergent pinnacles, the dominant species was Ficus prolixa. These forests also contained a wide range of species including Ochrosia elliptica, Barringtonia asiatica, Calophyllum, Terminalia, Premna, Derris trifoliata, Clerodendrum inerme, and Colubarina asiatica. Except for Lantana camara and Psidium guajava, the limestone plateau forest and the escarpment forest were composed of species native to the Pacific Islands.

Surrounding Buada Lagoon, there are open areas of marshy vegetation and home gardens that grade into closed to semiclosed forests of mixed native and naturalized species. Common components of these forests are Calopbyllum, Terminalia, Ceiba pentandra, Adenanthera pavonina, Mangifera indica, and Annona sp. In Meneñ, Anabar, and Anetan Districts, small landlocked lagoons and ponds containing the mangrove Bruguiera gymnorbiza occur (Thaman et al. 1994). MuellerDombois and Fosberg (1998) also reported Rhizophora apiculata from Nauru.

The coastal fringe vegetation has been modified by human activities and settlement such that this area now is a mosaic of 
natural, disturbed, and cultivated vegetation. The original outer coastal zone is characterized by the presence of salt-tolerant woody species such as Tournefortia argentea, Morinda citrifolia, and Scaevola taccada and the herbs Vigna marina, Lepturus repens, and Ipomoea pescaprae. Inland from the shore, the vegetation is composed of species found in more mesic conditions. In addition to species common to the plateau limestone forest, the vegetation contains Hibiscus tilaceus, Cocos nucifera, Hernandia nymphaefolia, and many panPacific herbs and food and ornamental species (many species now found in this inner coastal zone are not native to the Pacific Islands but were introduced into Nauru after European contact).

The fauna of Nauru is very sparse. Before European contact, a number of birds are known to have resided on the island (white terns, Gygis candada; white-capped noddies, Micranous leucocapillus; frigate birds, Tachypetes aquilus [noddies are still present]), but no other animals were recorded except for a native rat (Mus exulans) (Power 1904). Food in ancient times was based on fish, coconuts, and pandanus, although seabirds were caught and eaten occasionally.

TIme. The evolution of Nauru as an island was described by Hill and Jacobson (1989), but some aspects of the time available for soil formation on Nauru are subject to debate. The island probably began as a basaltic dome arising over the Samoa hot spot about $40 \mathrm{Ma}$. With proximity to the ocean surface, reef growth led to a limestone cap being developed to a depth of around $500 \mathrm{~m}$. The island may have existed as a low atoll at some time. At some point the limestone cap was above sea level for sufficient time for karstification to occur and for phosphatic material to accumulate over the karst. The origin of the phosphate material has not been confirmed; most authors (Power 1904, Hutchinson 1950, Roe and Burnett 1985) have suggested that the origin is avian guano that has been reworked as a result of the submergence and uplift of the island, but others (Owen 1923, Barrett 1988) have suggested (without much scientific evidence) alternative geochemical mechanisms. One criticism of the avian theory is the Holocene climate: Nauru is wet- ter than other areas where guano has been converted into high-quality apatite. Hutchinson (1950) addressed this by suggesting that Nauru may have been drier during Glacial periods and this would have allowed phosphate rock to form. It is one of the great disappointments of the Nauru story that this issue has not been resolved to any degree of scientific satisfaction.

Hill and Jacobson (1989) indicated that the last emergence occurred during the last Glacial low about $18,000 \mathrm{yr}$ ago, possibly relating to uplift of the Pacific Plate as it rode over a minor thermal anomaly. Roe and Burnett (1985) dated the phosphate material at $>300,000$ ybp, and Piper et al. (1986) reported foraminifera in the rock at up to 11 million yr old, so the karst and superimposed phosphate must have been in place at the time of the last emergence. Samples from the coastal fringe have been radiocarbon dated at around 2,800 ybp, clearly showing the recent evolution of this section of the island. Assuming that the island did emerge from the ocean about 18,000 yr ago, there would have been time for the vegetation to develop as we have outlined and soil formation to occur.

\section{Processes of Soil Formation on Nauru}

Given that the parent materials of Nauru soils are either resistant to weathering (apatite) or weather relatively easily (carbonates by dissolution) without producing noncarbonate minerals, and that the island has been above sea level for only $18,000 \mathrm{yr}$, the dominant process of soil formation probably has been organic matter accumulation. Dissolution and precipitation of carbonates probably also occurred, but in a carbonate-rich environment this has little impact on the soils. Other possible processes, such as mineral transformations, oxidation, and reduction, were not important in Nauru. The phosphatic material is generally coarse, with very small proportions $<63 \mu \mathrm{m}$ (usually $<1 \%$ ), and the reef limestone would have fragmented easily until the particle size was small enough for dissolution to become important. The soils are therefore generally coarse textured, having low moisture retention with rapid infiltration and water transmission rates. Dissolved carbonates and 
other elements are leached through the soils quickly.

Slope influences probably were small, because the high porosity of the soils and the underlying limestone almost certainly encouraged infiltration as opposed to overland flow, and the slopes, apart from the scarp, generally were relatively gentle. Some movement of organic matter downslope probably occurred, particularly into the area around Buada Lagoon, and thus some deeper A horizons might be expected in the depressions on Topside.

The extent of accumulation of organic matter depends on the nature of the vegetation (production), the rate of decomposition, and slope position. No evidence was found that any vegetative matter produced on $\mathrm{Na}$ uru was particularly resistant to breakdown (i.e., likely to accumulate). Production of vegetative material is controlled by rainfall, and, given the history of climate variability, this is likely to have changed from year to year. Given the hot humid climate and the aerated nature of most soils, the organic matter decomposition rate is likely to have been high, indicating that equilibrium likely was attained without development of large amounts of soil organic matter and very deep A horizons. In addition, loss of organic matter occurred when soils were exposed following vegetation disturbance (as has been observed on other Pacific atolls) (Morrison 1992).

Analysis of soil-forming processes indicate that the soils of Nauru generally have $\mathrm{AC}$ profiles, because there are no processes likely to occur that would have produced significant B horizons. Some minor color variations occur in the phosphatic material due to weathering of the very small quantities $(<0.5 \%)$ of iron present, but these are not sufficient to designate a $\mathrm{B}$ horizon. The depth and color of the A horizons depend on the vegetation type, surface coverage, and slope position.

\section{A Note on Classification}

All soils studied were classified according to the U.S. Department of Agriculture soil taxonomy system (Soil Survey Staff 1975, 1996). Two interesting problems arose in the classi- fication of soils of Nauru. The first is the determination of the soil moisture regime. No direct measurements of soil moisture are available, and the estimation of soil moisture regimes had to be based on meteorological data. As noted earlier, mean annual precipitation is about 2,000 $\mathrm{mm}$ (range, 280-4,500 $\mathrm{mm}$ ), with 4 months, on average, having rainfall below $100 \mathrm{~mm}$. Air temperatures ranged from 23 to $35^{\circ} \mathrm{C}$ with the relative humidity $>70 \%$. Nauru is periodically affected by droughts, and several droughts of more than 12 months duration were recorded during the twentieth century. However, taking the average rainfall data available, and assuming evapotranspiration rates averaging $4-5 \mathrm{~mm}$ per day in the nondrought years, it appears that the soils of Nauru not influenced by the effects of groundwater fit best into the ustic moisture regime (Van Wambeke 1981).

The second issue relates to soil structure. Several pedons on Nauru meet all the requirements for classification as Mollisols if they have sufficiently good soil structure in the A horizon. As with many soils developed on coarse materials, structure was not a pronounced feature. Many of the profiles examined on Topside had weakly developed granular structure and a few had moderately developed structures. If structure could be clearly distinguished in the bulk of the horizon, this was considered sufficient, where appropriate, to designate the soils as Mollisols.

\section{The General Soil Pattern on Nauru before Mining}

The soils of Nauru can be divided into three (or possibly four) groups depending on landform position: the coastal fringe, the scarp, and the Topside depressions and the more-elevated areas on the outer parts of Topside. The area around Buada Lagoon may be treated separately or as a variant of what is found in the Topside depressions. A map illustrating the distribution of the soils is shown in Figure 3. Physical and chemical data from typical Nauru pedons are summarized in Table 2.

COASTAL fringe soils. Around the edge of the island lies a narrow fringing reef on which weakly developed soils occur, usually 


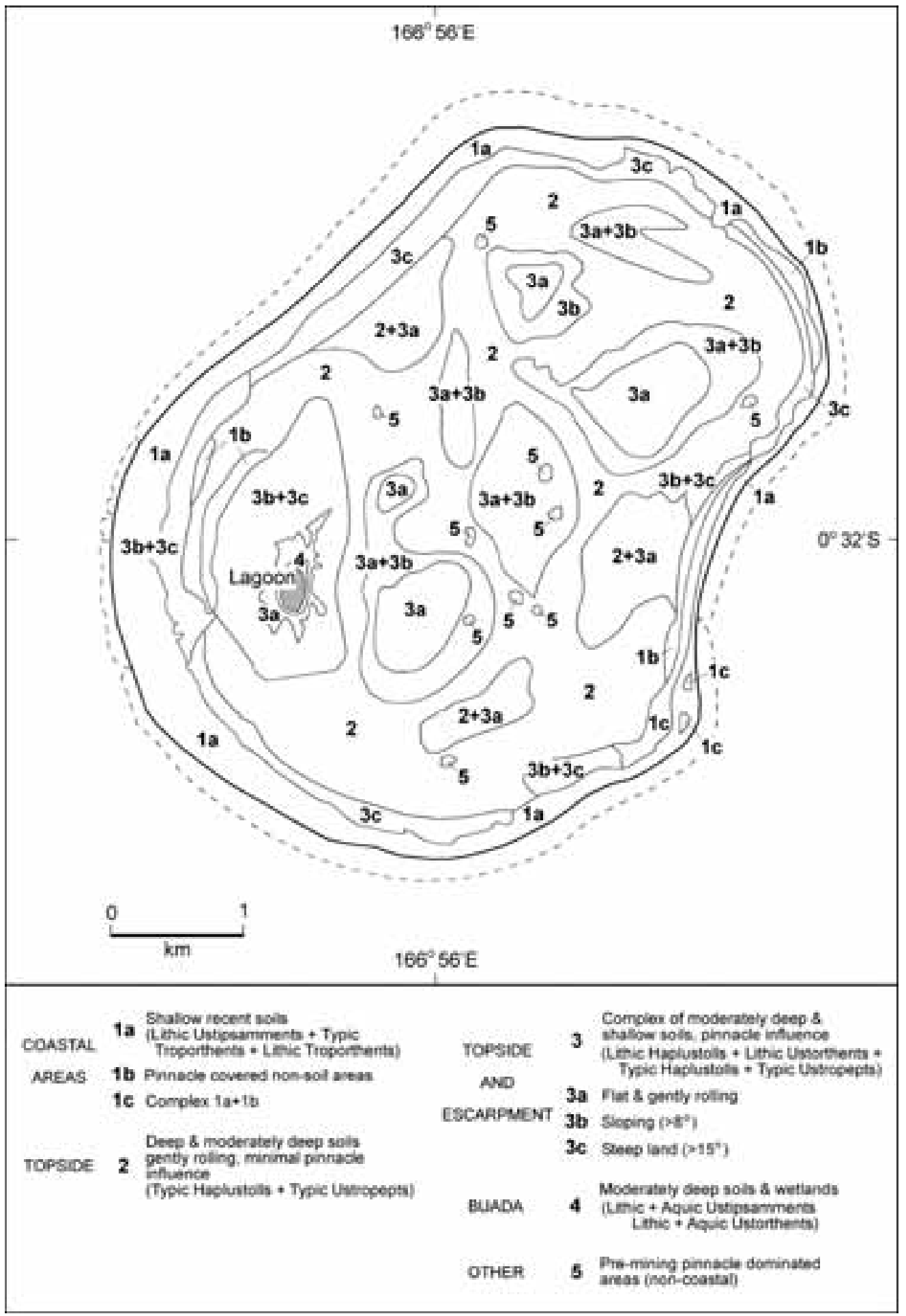

Figure 3. Proposed soil pattern of Nauru before phosphate mining. 
TABLE 2

Some Physical and Chemical Data for Typical Nauru Soils

\begin{tabular}{lccccccccc}
\hline \hline Pedon & $\begin{array}{c}\text { Horizon } \\
\text { Nepth }(\mathrm{cm})\end{array}$ & $\begin{array}{c}\mathrm{pH} \\
\left(\mathrm{H}_{2} \mathrm{O}\right)\end{array}$ & $\begin{array}{c}\mathrm{OC} \\
(\%)\end{array}$ & $\begin{array}{c}\mathrm{N} \\
(\%)\end{array}$ & $\begin{array}{c}\text { Total } \\
\mathrm{P}(\%)\end{array}$ & $\begin{array}{c}\text { Olsen } \\
\mathrm{P}(\mathrm{mg} / \mathrm{kg})\end{array}$ & $\begin{array}{c}\mathrm{CEC} \\
(\mathrm{cmol} / \mathrm{kg})\end{array}$ & $\begin{array}{c}\text { Moisture } \\
30 \mathrm{kPa}\end{array}$ & $\begin{array}{c}\text { Retention }(\%) \\
1,500 \mathrm{kPa}\end{array}$ \\
\hline NRU 1 & $0-24$ & 6.7 & 6.41 & 0.32 & 15.11 & 107 & 37.7 & 25.9 & 21.4 \\
& $24-53$ & 6.8 & 2.94 & 0.18 & 16.27 & 55 & 21.1 & 22.3 & 18.9 \\
& $53-100$ & 6.7 & 0.41 & 0.08 & 16.95 & 91 & 18.2 & n.d. & 17.2 \\
NRU 2 & $100-200$ & 6.7 & 0.51 & 0.07 & 16.94 & 202 & 18.2 & n.d. & n.d. \\
& $0-10$ & 6.6 & 2.74 & 0.21 & 16.99 & 6 & 26.8 & 22.5 & 17.0 \\
& $30-40$ & 6.6 & 0.97 & 0.12 & 17.5 & 21 & 6.5 & 21.6 & 16.4 \\
NRU 3 & $60-80$ & 5.9 & 0.48 & 0.04 & 17.06 & 286 & 5.8 & n.d. & 16.8 \\
& $130-150$ & 6.0 & 0.41 & 0.04 & 17.37 & 112 & 5.0 & n.d. & 22.5 \\
NRU 4 & $0-10$ & 6.0 & 2.34 & 0.14 & 17.14 & 14 & 11.6 & 21.6 & 16.4 \\
& $25-35$ & 6.1 & 0.61 & 0.07 & 17.29 & 20 & 11.7 & 24.0 & 20.1 \\
& $10-120$ & 6.3 & 0.33 & 0.03 & 17.52 & 28 & 17.0 & n.d. & 10.0 \\
NRU 5 & $0-9$ & 6.5 & 5.64 & 0.41 & 13.11 & 2 & 31.8 & 25.7 & 21.1 \\
& $9-20$ & 7.7 & 1.94 & 0.29 & 15.32 & 7 & 9.6 & n.d. & 8.5 \\
NRU 8 & $0-28$ & 8.3 & 0.39 & 0.09 & 4.48 & 2 & 5.5 & n.d. & 5.2 \\
& 12 & 8.2 & 4.06 & 0.29 & 2.13 & $<1$ & 13.8 & 13.2 & 6.4 \\
& $0-30$ & 8.2 & 0.29 & 0.03 & 0.28 & $<1$ & 2.8 & n.d. & 2.1 \\
NRU 25 & $25-35$ & 5.9 & 3.81 & 0.23 & 15.15 & 6 & 17.4 & 23.1 & 19.9 \\
& $60-80$ & 6.4 & 0.94 & 0.13 & 16.96 & 175 & 6.5 & 25.8 & 24.1 \\
& $120-130$ & 6.3 & 0.12 & 0.06 & 17.43 & 204 & 6.8 & n.d. & 17.0 \\
\hline
\end{tabular}

n.d., no data.

consisting of a thin A horizon of coral sand and rubble showing some organic matter accumulation over limestone. The maximum depth of the A horizon is about $10-12 \mathrm{~cm}$. The soils vary in physical composition with differing proportions of coral sand and larger fragments occurring in the soils. In small areas where the coastal strip is low lying, these soils can be quite moist, especially in wet years. In a small area around the NE corner of the island (Anabar), a small area $(<5$ ha) of pinnacle terrain occurs in which several small brackish lagoons are located. This area has effectively no soils.

Only very limited laboratory data are available for these soils. Soil $\mathrm{pH}$ values were in the range $6.8-8.0$; organic carbon was around $2-$ $3 \%$ in relatively undisturbed soils and less in disturbed profiles; cation exchange capacities (CECs) were 12-20 $\mathrm{cmol} / \mathrm{kg}$; and all soils had substantial contents of calcium carbonate (usually $>40 \%$ ). X-ray diffraction showed a dominance of calcite with smaller contents of aragonite and small quantities $(<5 \%)$ of apatite and dolomite.
These coastal fringe soils of Nauru are similar to soils of some of the low atolls in the Pacific (e.g., Tarawa in Kiribati [Morrison 1990]). Because deep sand accumulations are rare, most of the soils are Lithic Ustipsamments, Typic Troporthents, or Lithic Troporthents. In a very few locations where water accumulation near the surface occurred, aquic features were identified but to an insufficient extent to map separately.

DEEP AND MODERATELY DEEP SOILS OF TOPSIDE. These soils are generally located toward the NE, NW, SE, and SW sections of Topside, where phosphate rock had accumulated to a substantial depth (at least $1 \mathrm{~m}$ ) above the pinnacles. These soils were formed from phosphatic materials with minimal influence of limestone and are characterized by gently undulating terrain. Scattered gravels, stones, and small boulders are frequently found on the soil surface-whether this was natural or the effect of human activities could not be determined. The profiles are coarse textured, having dark gray (10 YR 3/1-4/1), very dark brown (10 YR 2/2), or very dark 
grayish brown (10 YR 3/2) A horizons, varying in depth from 13 to $30 \mathrm{~cm}$. In many profiles a mixed AC layer (10 YR 4/2-6/2) up to $25 \mathrm{~cm}$ deep occurs below the A horizon, but in some the A to $\mathrm{C}$ transition is quite sharp. No specific pattern could be found in this behavior.

Below the layers of organic accumulation, some minor color changes (pinkish white [7.5 YR 7/4] or very pale brown [10 YR 8/4] to pinkish white [7.5 YR 8/2]) were observed. Initially it was believed that these were indicative of $B$ horizon formation. Later examination showed that they were often related to soil wetness (dried materials were almost uniform in color), and no significant textural, mineralogical, or chemical changes could be determined in the laboratory analysis. They were therefore designated as $\mathrm{C}$ horizons. These subsurface layers are all very coarse and vary in the content of stones and boulders. Roots penetrated to about $1 \mathrm{~m}$ depth but seldom deeper.

Soil $\mathrm{pH}$ values were $6.0-7.0$ in water for topsoils and 4.9-6.1 in $\mathrm{KCl}$; in subsoils they ranged from 5.9 to 7.7 in water and from 5.3 to 6.7 in $\mathrm{KCl}$. Organic carbon contents ranged from 2.7 to $6.4 \%$ for topsoils and from 0.1 to $0.9 \%$ for subsoils. In all profiles there was a regular decrease in organic carbon with depth. Total nitrogen ranged from 0.21 to $0.32 \%$ in topsoils and from $<0.1$ to $0.13 \%$ in subsoils. CECs varied from 17 to $38 \mathrm{cmol} / \mathrm{kg}$ in topsoils and from 5 to 21 $\mathrm{cmol} / \mathrm{kg}$ in subsoils. As with most Nauru soils there was a very strong correlation $\left(r^{2}=0.9\right)$ between CEC and organic carbon. Exchangeable $\mathrm{Mg}$ varied from 0.8 to $8.3 \mathrm{cmol} / \mathrm{kg}$ for topsoils and from $<0.1$ to $4.9 \mathrm{cmol} / \mathrm{kg}$ for subsoils; exchangeable $\mathrm{K}$ values in topsoils ranged from 0.1 to $0.3 \mathrm{cmol} / \mathrm{kg}$ for topsoils and were almost all $<0.1 \mathrm{cmol} / \mathrm{kg}$ for subsoils. Total $\mathrm{P}$ values ranged from 15.1 to $16.4 \%$ for topsoils and from 16.0 to $17.5 \%$ for subsoils; Olsen (available P) varied from 10 to $33 \mathrm{mg} / \mathrm{kg}$ for topsoils and from 9 to 39 $\mathrm{mg} / \mathrm{kg}$ for subsoils.

The deep and moderately deep soils of Topside were classified as being Typic Haplustolls if they had sufficiently deep dark surface layers and identifiable structure. If there was insufficient structure development or the dark layers were not deep enough for mollic horizons, they were classified as Typic Ustropepts.

The distribution of the deeper profiles in the NE, NW, SE, and SW Topside locations has been the subject of some speculation. No simple explanation is obvious, and the answer must to some extent relate to the nature of the phosphatic material genesis. One suggestion is that if the rock is of guano origin, then the bird ecology was a major factor (e.g., nesting preference, sites of takeoff and landing).

RELATIVELY FLAT, SLOPING, AND STEEPLAND SOILS WITH DOLOMITE PINNACLE INFLUENCE. Three distinct profile types were identified in this category. These are illustrated in Figure 3. The relatively flat areas where this combination of profiles occurs are in the Topside depressions, and the sloping (i.e., $8-15^{\circ}$ ) areas occur on the slopes from the depressions up to the higher sections of Topside and on limited parts of the scarp, especially on the middle sections in the east and west. The steepland soils (slopes $>15^{\circ}$ ) occur over the rest of the scarp and on some of the slopes from the Buada Lagoon area up to Topside.

The three separate profiles consisted of:

1. A dark gray or dark brown epipedon overlying a layer of mixed phosphatic material and broken dolomitic limestone, which in turn lies on pinnacle dolomite. Such profiles have been classified as Lithic Haplustolls.

2. A thin $(<12 \mathrm{~cm})$ dark gray or dark brown epipedon directly overlying the pinnacle dolomitic limestone substratum: classified as Lithic Ustorthents. Pinnacles occasionally reached almost to the soil surface.

3. Where the phosphatic material has accumulated between limestone pinnacles, the profile showed a deeper $(>20 \mathrm{~cm})$ dark gray or dark brown epipedon overlying material that was frequently reddish yellow (7.5 YR 7/4) between 25 and $75 \mathrm{~cm}$ depth, changing to pinkish gray $(5 \mathrm{YR} 7 / 2)$ at greater 
depth. The subsoil horizons were occasionally stony or bouldery throughout. These deep and moderately deep soils of Topside were classified as being Typic Haplustolls if they had sufficiently deep, dark surface layers and identifiable structure. If there was insufficient structure development or the dark layers were not deep enough for mollic horizons, they were classified as Typic Ustropepts.

Scattered gravels, stones, and small boulders were again frequently found on the soil surface. The soils were all coarse textured, often with many stones or larger fragments in the surface layers, and the deeper profiles were often stony and bouldery. Root penetration varied with profile depth but was seldom deeper than $1 \mathrm{~m}$.

Soil $\mathrm{pH}$ values were $6.5-7.7$ in water for topsoils and 5.9-6.8 in $\mathrm{KCl}$; in subsoils they ranged from 7.1 to 8.3 in water and from 6.0 to 7.8 in $\mathrm{KCl}$. Organic carbon contents ranged from 5 to $6 \%$ for topsoils and from 0.3 to $1.9 \%$ for subsoils. In all the deeper profiles, there was a regular decrease in organic carbon with depth. Total nitrogen ranged from 0.2 to $0.4 \%$ in topsoils and from $<0.1$ to 0.29 in subsoils. CEC varied from 17 to $38 \mathrm{cmol} / \mathrm{kg}$ in topsoils and from 6 to 10 $\mathrm{cmol} / \mathrm{kg}$ in subsoils. Exchangeable $\mathrm{Mg}$ varied from 5.8 to $10.3 \mathrm{cmol} / \mathrm{kg}$ for topsoils and from $<2.9$ to $3.6 \mathrm{cmol} / \mathrm{kg}$ for subsoils. Exchangeable $\mathrm{K}$ values in topsoils ranged from 0.2 to $0.3 \mathrm{cmol} / \mathrm{kg}$ for topsoils and in subsoils were all $<0.2 \mathrm{cmol} / \mathrm{kg}$. Total $\mathrm{P}$ values ranged from 13.1 to $14.6 \%$ for topsoils and from 15.3 to $16.4 \%$ for subsoils; Olsen (available) $\mathrm{P}$ varied from 2 to $36 \mathrm{mg} / \mathrm{kg}$ for topsoils and from 7 to $68 \mathrm{mg} / \mathrm{kg}$ for subsoils.

SOILS OF THE BUADA LAGOON AREA. Around the Buada Lagoon, the presence of community housing and gardens has limited the extent of mining. Many of the soils have been disturbed by building and gardening but mainly only the upper layers $(<50 \mathrm{~cm})$. The soils in this are of three types:

1. Pinnacle-influenced profiles similar to those described for the Topside depressions.
2. On sloping and steepland areas where the dolomite pinnacle influence is dominant soils occur either as very thin accumulations over pinnacles or as pockets $(<1 \mathrm{~m}$ deep) between the pinnacles. Topsoils are usually very dark brown (10 YR 2/2) or dark brown (10 YR 3/2) and subsoils yellowish brown (10 YR 5/4) or pale brown (10 YR 6/3). All soils were coarse textured, with substantial contents of stones and gravels, and boulders being common in the steeper slope profiles.

3 . In very limited areas close to the old lagoon, where groundwater influence is substantial most of the time, the soils have been exploited for gardening and have therefore seen much disturbance. They are black (10 YR 2/1) or less commonly very dark brown (10 YR 2/2), coarse textured, often stony and gravely and sometimes peaty. Profile depths are variable: A horizons average about 18 $\mathrm{cm}$ (range, 12-25), on top of unconsolidated materials to a depth of about $60 \mathrm{~cm}$. These soils were classified as Lithic or Aquic Ustipsamments or Ustorthents depending on the particle coarseness and extent of groundwater influence.

No laboratory data are available for the Buada region soils.

\section{Soil Properties: Some General Comments}

physical properties. The soils of Nauru are dominantly coarse textured. Sands, sandy loams, and loams with various amounts of gravel, stones, and boulders are dominant. The soils generally have weakly to moderately developed granular or crumb structures in the surface layers, and subsoils are usually structureless or have only very weakly developed structures. The moisture-retention properties can be related to the textures; moisture retention is generally low. Measurements of moisture retention against $1,500 \mathrm{kPa}$ tension never exceeded $25 \%$ and were frequently less than $10 \%$ (Table 2). Water retention against $30 \mathrm{kPa}$ tension ranged from 8 
to $26 \%$, and estimations of plant available water were low for most Nauru soils. This is confirmed by the vegetation pattern, which shows the dominance of species able to tolerate some moisture stress. The soils are excessively well drained or well drained, showing that the heavy rains are rapidly moved away from the surface layers.

Chemical properties. As with many Pacific Island soils, the influence of organic matter on other Nauru soil properties is critical. There was a very strong correlation of CEC with organic carbon $\left(r^{2}=0.9\right)$. A significant correlation $\left(r^{2}=0.6\right)$ was also found between water retention against $1,500 \mathrm{kPa}$ tension and organic carbon. The disturbance of almost all the soils of Nauru as a result of mining, housing, or road construction and the resulting loss of organic matter is a major issue when considering possible future foodproduction options.

FERTILITY. Before mining, the soils of Nauru probably were more fertile than those of many Pacific atolls (Morrison 1990), but overall fertility was limited. Concentrations of organic matter (as indicated by organic carbon contents) were relatively high (often $>5 \%$ ) and the nitrogen content was high enough to maintain any subsistence cropping. Exchangeable potassium concentrations were generally low, and because the soils usually had free lime in the profiles potassium uptake by plants probably was inhibited by the excessive levels of calcium present. Phosphorus is obviously adequate (as seen in the Olsen $\mathrm{P}$ values in Table 2) for all plant needs except in some of the soils of the coastal reef area. Sulfate levels are moderate (phosphate extractable $\mathrm{S}$ ranging from 1 to $88 \mathrm{mg} / \mathrm{kg}$ ) but are adequate for nonintensive farming.

No specific information has been obtained on the trace elements in Nauru soils. Data from analysis of "run of mine" phosphate rock show, however, that total concentrations of manganese $(20-50 \mathrm{mg} / \mathrm{kg})$, copper $(5-20 \mathrm{mg} / \mathrm{kg})$, cobalt $(<1 \mathrm{mg} / \mathrm{kg})$, and $\mathrm{mo}-$ lybdenum $(<1 \mathrm{mg} / \mathrm{kg})$ are very low. Iron contents are around $0.3 \%$, and zinc contents range from 500 to $1,000 \mathrm{mg} / \mathrm{kg}$. Thus deficiencies in manganese, copper, cobalt, and molybdenum are to be expected. Added to this is the influence of soil $\mathrm{pH}$. The soils of Nauru have high $\mathrm{pH}$ values $(\mathrm{pH}>6.5$ generally). Under these conditions, elements such as iron, copper, zinc, and manganese are rendered unavailable to plants due to chemical immobilization. Thus trace element problems are likely to occur in any intensive cropping system on Nauru soils.

Two other factors that should be considered in assessing the fertility of Nauru are physical in nature. First is the influence of the pinnacles or other large coral fragments. These obviously hamper any mechanical cultivation and have a marked influence on rooting. In many Topside areas the pinnacle influence is substantial, and cropping would have to be carried out between the pinnacles, as is done, for example, in Niue. The other factor is moisture. This would have been a major constraint to any crop production. In the wet years, when rainfall is abundant, the soils of Nauru have considerable potential. Droughts are common, however, and the soils have only a limited capacity to retain moisture. Thus any intensive cropping in the drier years in the absence of external water supplies (irrigation) is likely to fail. This, in part, may explain the historical dependence on coconuts and other tree crops (Phillips and Haantjens 1954).

cadmium. Analysis of the data in the literature shows that the average cadmium content of uncontaminated soils is about $0.6 \mathrm{mg} /$ $\mathrm{kg}$ with a range of $<0.1-15 \mathrm{mg} / \mathrm{kg}$ (Ure and Berrow 1982). From the data available on cadmium in rocks, Page and Bingham (1973) suggested that soils derived from sedimentary materials (such as those on Nauru) should contain $0.3-11 \mathrm{mg} / \mathrm{kg}$. Total cadmium concentrations of Nauru soils were generally in the range of $80-120 \mathrm{mg} / \mathrm{kg}$, considerably greater than the cited values. A very limited study of calcium chloride extractable cadmium showed values in the range of $0.06-$ $0.18 \mathrm{mg} / \mathrm{kg}$ (R.J.M., unpubl. data). Because calcium chloride is a weak extractant these values are high. Thus both total and extractable cadmium levels in Nauru soils are well above global averages. This $\mathrm{Cd}$ content led to production of superphosphate containing substantial Cd concentrations; the impact on Australian soils and agriculture has been the 
subject of recent research (Williams and David 1973, Mann and Ritchie 1994).

Cadmium is not essential to the growth of plants or animals but is highly toxic to both. The long-term persistence in soils, rapid uptake by plants, and accumulation of toxic concentrations by plants and animals give some cause for concern over cadmium levels in soils. Uptake of cadmium by plants from the soil is controlled by many factors including the plant itself, but soil $\mathrm{pH}$ is a particularly important factor (Williams and David 1973). The solubility of cadmium decreases in soils as the $\mathrm{pH}$ increases. Thus in Nauru soils the high $\mathrm{pH}$ limits the movement of cadmium into plants and hence into other parts of the environment. A complicating factor for $\mathrm{Na}$ uru soils is that $\mathrm{Cd}$ movement increases with soil salinity (McLaughlin et al. 1997). Because Nauru is a small island surrounded by ocean the rainwater contains some salt, and this may have led to increased $\mathrm{Cd}$ mobility in soils. There is also some evidence to indicate that, in some plants, cadmium accumulates in the roots, which restricts transport to other (above-ground) parts of the plants (Williams and David 1973).

Analysis of some food-plant materials from Nauru (Naidu and Morrison, reported in Commission of Inquiry 1988) showed that edible portions usually contained less $\mathrm{Cd}$ than nonedible portions (Table 3). Although no specific studies have been made on Cd intakes through traditional diets in Nauru, some preliminary data can be found in Blake (1992). The fact that edible portions of food plants had lower Cd concentrations may have been important in maintaining the health of the community. Blake (1992) also reported that analysis of several fish species showed $\mathrm{Cd}$ contents in fish flesh of $<0.1 \mathrm{mg} / \mathrm{kg}$, and shellfish Cd concentrations were generally $<5 \mathrm{mg} / \mathrm{kg}$, indicating that Cd uptake from marine sources would not be excessive.

Recent attempts to assess the maximum levels of $\mathrm{Cd}$ in food have recommended that for root and vegetable crops the concentrations should be less than $0.05-0.2 \mathrm{mg} / \mathrm{kg}$ (varies with crop) (Ministry of Agriculture, Forestry, and Fisheries 2004). A number of the Nauru foods (Table 3) exceed these concentrations.

\section{The Postmining Soil Pattern}

During the studies on Nauru it was possible to locate areas where the mining history was accurately known. In these areas, attempts

TABLE 3

Cd Concentrations (mg/kg dry weight) in Some Nauru Food Plants

\begin{tabular}{llll}
\hline \hline Site & Plant & Sample Type & Cd \\
\hline Topside workshop garden & Banana & Edible portion & 0.13 \\
& & Nonedible & 0.19 \\
& Sweet & Edible portion 1 & 0.28 \\
& potato & Edible portion 2 & 0.30 \\
Buada Lagoon east shore & & Nonedible & 4.1 \\
& Sugarcane & Edible portion & 0.15 \\
& & Nonedible & 0.36 \\
& Papaya & Edible portion & 0.23 \\
Buada Lagoon west shore & Banana & Nonedible & 1.7 \\
& & Edible portion & 0.09 \\
Topside roadside (Meneñ District) & Pandanus & Nonedible & 0.23 \\
& & Edible & 0.89 \\
Anabar, Anibare, Aiwo, Meneñ, Buada & Papaya & Nonedible & 0.98 \\
& & Edible portion & 0.15 \\
& Coconut & Nonedible & 0.51 \\
\hline
\end{tabular}

Source: Naidu and Morrison, reported in Commission of Inquiry 1988; coconut data from Blake (1992). 
were made to find sites that had been left undisturbed (or nearly so) since the time of mining. The vegetation regeneration on minedout sites was discussed in detail by Manner et al. (1984, 1985). At each regeneration site, composite soil samples were collected and analyzed to see if any patterns could be observed. Manner and Morrison (1991) found that there was a relatively rapid buildup in soil organic matter (as measured by $\mathrm{C}$ and $\mathrm{N}$ ) if the soil was developing on unconsolidated phosphate material at a site left undisturbed after mining. This is extremely important because many soil parameters (e.g., cation exchange capacity, moisture retention capacity) are closely related to the soil organic matter content. It was not possible to detect any buildup of soil structure because the soils are mainly sands, and structure development in sandy soils is usually only weak in the best of situations.

Decisions have been made to re-mine some of the areas previously abandoned, and this secondary mining will obviously impact on any regenerating soils. A field survey in the mid-1990s (R.J.M., Hassall, and Hunter, unpubl. data) showed that all of Topside was impacted, with only very small remnant forest tree patches remaining. Almost all of the Topside soils had been removed, and given the small volumes of unconsolidated materials left, the nature of the "new" vegetation, and the porosity of the underlying substratum, it is unlikely that anything other than very shallow surficial accumulations of organic material will develop. There was no evidence of soil development on the pinnacles because most plants seemed unable to gain any foothold in these massive materials; the exception is Ficus prolixa.

Thus the island postmining has four soil associations: (1) the coastal fringe, where patches of the shallow AC profiles remain. Undisturbed areas are becoming less common; (2) the escarpment slope complex, where patches of moderately shallow and shallow soils remain because they were too difficult to mine; (3) the pinnacle-dominated Topside, with very small patches of remnant forest and the associated soils (this covers about $80 \%$ of the island surface). There are places where soils have started to develop under the postmining vegetation between pinnacles, giving thin, coarse structureless A horizons, probably in many cases failing to qualify as a soil; (4) areas close to Buada Lagoon, where some moderately deep soils remain, along with areas in home gardens and the limited wetland areas adjacent to the lagoon.

The topsoil material that has been stockpiled could be used to regenerate about 100 ha of land. It has been suggested (Commission of Inquiry 1988) that this material could be spread over an area where the pinnacles have been flattened (this would involve substantial cost), but effective regeneration would be assisted by the use of some poorer-quality phosphate material as a base below the topsoil to stop the valuable organic-rich material from falling into the crevices between the broken pinnacles. Even if such a system could be established, long-term soil generation will require vegetation (that is no longer available), and the development of any sustainable tree/garden system would also need regular water inputs, which may not always be available once shipping to Nauru is dramatically reduced when mining is terminated.

\section{CONCLUSIONS}

The soils of Nauru, derived from high-purity apatite, formed a relatively unique feature in the Pacific islands (along with those of Ocean Island in Kiribati and Makatea in French Polynesia). The original Nauru soils included areas of Mollisols, a surprising component for an atoll environment.

The vast bulk of the soils of Nauru has been removed by phosphate-mining activities; there will be no regeneration of these soils, and a lack of research before and during mining means that features such as Mollisol development and other issues relating to soil formation will remain unresolved.

\section{Literature Cited}

Barrett, P. J. 1988. Report on phosphate, other minerals and groundwater resources, and other aspects of rehabilitation plan- 
ning and methodology, Nauru, Pacific Ocean. Pages 0948-0998 in Report, Commission of Inquiry into the rehabilitation of mined-out phosphate lands of Nauru, Vol. 9. Government of Nauru, Meneñ.

Barrow, N. J., and T. C. Shaw. 1977. Sodium bicarbonate as an extractant for soil phosphate, II. Effect of varying the conditions of extraction on the amount of phosphate initially displaced and on the secondary adsorption. Geoderma 16:109-123.

Blake, C. 1992. Environmental distribution of heavy metals on Nauru, central Pacific, and possible relationships to human health. B.Appl.Sci. Honours Report, University of New England, Northern Rivers, Lismore, New South Wales, Australia.

Blakemore, L. C., P. L. Searle, and B. K. Daly. 1981. Methods of chemical analysis of soils. N. Z. Soil Bur. Sci. Rep. 10A (Revised), Wellington.

Commission of Inquiry. 1988. Report of the Commission of Inquiry into the rehabilitation of the mined-out phosphate lands of Nauru. 10 vols. Government of Nauru, Meneñ.

Gangaiya, P., U. Singh, and R. J. Morrison. 1982. The relationship between clay content and 15 bar moisture retention for some Fiji soils. N. Z. J. Sci. 25:61-64.

Hill, P. J., and G. Jacobson. 1989. Structure and evolution of Nauru Island, central Pacific Ocean. Aust. J. Earth Sci. 36:365381.

Hutchinson, G. E. 1950. The biogeochemistry of vertebrate excretion. Bull. Am. Mus. Nat. Hist. 96:1-556.

Jacobson, G., and P. J. Hill. 1988. Hydrology and groundwater resources of Nauru Island, central Pacific Ocean. Record 1988/ 12, Bureau of Mineral Resources, Geology and Geophysics, Canberra, Australia.

Lee, G. W., U. Singh, and R. J. Morrison. 1982. The determination of organic carbon in South Pacific soils. South Pac. J. Nat. Sci. 4:34-42.

Mann, S. S., and G. S. Ritchie. 1994. Changes in the forms of cadmium with time in some West Australian soils. Aust. J. Soil Res. 32:241-250.

Manner, H. I., and R. J. Morrison. 1991. A temporal sequence (chronosequence) of soil carbon and nitrogen development after phosphate mining on Nauru Island. Pac. Sci. 45:400-404.

Manner, H. I., R. R. Thaman, and D. C. Hassall. 1984. Phosphate mining induced vegetation changes on Nauru Island. Ecology 65:1454-1465.

- 1985. Plant succession after phosphate mining on Nauru. Aust. Geogr. 16:185-195.

McLaughlin, M. J., K. G. Tiller, and M. K. Smart. 1997. Speciation of cadmium in soil solution of saline/sodic soils and relationship with cadmium concentrations in potato tubers. Aust. J. Soil Res. 35:1-17.

Ministry of Agriculture, Forestry, and Fisheries (MAFF). 2004. Results of the discussion on International Standards regarding maximum levels of cadmium at the Codex Committee. MAFF Update No. 557, Tokyo, Japan.

Morrison, R. J. 1987. Comments on the soils of Nauru. Report prepared for the Commission of Inquiry into the rehabilitation of the mined-out phosphate lands of $\mathrm{Na}$ uru. Institute of Natural Resources, University of the South Pacific, Suva, Fiji. [Available from USP.]

. 1990. Pacific atoll soils: Chemistry, mineralogy and classification. Atoll Res. Bull. 339:1-25.

- 1991. Some Andisols from Savaici, Western Samoa. Soil Sci. Soc. Am. J. 55:159-164.

-1992. Physical and chemical limitations to increased agricultural production on atoll soils. Pages 27-36 in R. C. Chase, ed. Review of agricultural development in the atolls. University of the South Pacific, Apia, Samoa.

Mueller-Dombois, D., and F. R. Fosberg. 1998. Vegetation of the tropical Pacific islands. Springer, New York.

Murphy, J., and J. P. Riley. 1962. A modified single solution method for the determination of phosphate in natural waters. Anal. Chim. Acta 27:31-36.

Owen, L. 1923. Notes on the phosphate deposit of Ocean Island. Q. J. Geol. Soc. Lond. 79:1-15. 
Page, A. L., and F. T. Bingham. 1973. Cadmium residues in the environment. Residue Rev. 48:1-44.

Phillips, E., and H. A. Haantjens. 1954. Present and potential land use on Nauru. Record 54/3, Land Research and Regional Survey Section, Commonwealth Scientific and Industrial Research Organisation, Canberra, Australia. [Unpublished report, available from CSIRO.]

Piper, D. Z., B. Loebrier, and P. Aharon. 1986. Physical and chemical properties of the phosphate deposition on Nauru Island, western equatorial Pacific Ocean. Pages 177-194 in W. C. Burnett and S. R. Riggs, eds. Phosphate deposits of the world. Cambridge University Press, Cambridge, United Kingdom.

Power, F. D. 1904. Phosphate deposits of Ocean and Pleasant Islands. Proc. Aust. Inst. Mining Eng. 1:17-38.

Roe, K. K., and W. C. Burnett. 1985. Uranium geochemistry and dating of Pacific island apatite. Geochim. Cosmochim. Acta 49:1581-1592.

Soil Survey Staff. 1975. Soil taxonomy: A basic system of soil classification for making and interpreting soil surveys. U.S. Dep. Agric. Agric. Handb. 436.

. 1996. Keys to soil taxonomy. 7 th ed. U.S. Department of Agriculture Natural Resources Conservation Service, Washington, D.C.

Thaman, R. R. 1992. Vegetation of Nauru and Gilbert Islands: Case studies in poverty, degradation, disturbance, and displacement. Pac. Sci. 46:128-158.

Thaman, R. R., F. R. Fosberg, H. I. Manner, and D. C. Hassall. 1994. The flora of $\mathrm{Na}-$ uru. Atoll Res. Bull. 392:1-232.

Ure, A. M., and M. L. Berrow. 1982. Environmental chemistry. Spec. Period. Rep. 2:94-204.

Van Wambeke, A. 1981. Calculated soil moisture and temperature regimes for South America. U.S. Department of Agriculture, Soil Management Support Services, Technical Monograph 2, Washington, D.C.

Williams, C. H., and D. J. David. 1973. The effect of superphosphate on the cadmium content of soils and plants. Aust. J. Soil Res. 11: 43-56. 